\title{
Between-habitat interactions in coastal ecosystems: current knowledge and future challenges for understanding community dynamics
}

\author{
MASAKAZU HORI* \\ National Research Institute of Fisheries and Environment of Inland Sea, Fisheries Research Agency, 2-17-5 Maruishi, \\ Hatsukaichi, Hiroshima 739-0452, Japan
}

Received 18 September 2007; Accepted 24 January 2008

\begin{abstract}
Ecological communities are rarely formed within a single habitat and tend to include multiple habitats characterized by the influx and efflux of nutrients, detritus, prey and consumers among these habitats. Understanding these between-habitat effects on the community structure and dynamics has become important because this recognition may disprove previous ecological theories based on the processes within a single habitat. This paper reviews current knowledge of between-habitat interactions and their importance for community regulation in coastal ecosystems. First, I reviewed briefly some current knowledge about between-habitat interactions in general. Second, I summarized my empirical demonstrations examining the effects of allochthonous resources from subtidal habitats on the rocky intertidal community. The food web structure of the rocky intertidal habitat revealed that allochthonous sea urchins from the subtidal habitat affected the recipient food web structure and dynamics through the recipient avian predators, although the effects were different between the avian species with different foraging responses (numerical or functional). Understanding the effects of between-habitat interactions is important for the clarification of the spatial extent of community structure and habitat connectivity in landscape level, and thus indispensable for promotion of better coastal conservation and management.
\end{abstract}

Key words: Allochthonous input, consumer response, food web, rocky shore, spatial subsidies

\section{Introduction}

Almost all natural ecosystems are open and interact with other ecosystems in various ways (e.g. Anderson \& Polis 1998, Rose \& Polis 1998, Vinebrroke \& Leavitt 1998, Hilderbrand et al. 1999). The influx of nutrients, detritus and organic materials from a donor ecosystem to a recipient ecosystem is called "allochthonous input", and normally passes from the more productive (donor) into less productive (recipient) system and often facilitates the recipient (in situ) organisms (Polis \& Hurd 1995, Polis \& Strong 1996, Polis et al. 1997a, 1997b). Understanding the effects of the allochthonous input on the community structure and dynamics in the recipient habitat has become important because this recognition may change many previous ecological theories that purport to explain community structure and dynamics. For example, the EEH hypothesis (Oksanen

*Corresponding author: Masakazu Hori; E-mail: mhori@affrc.go.jp et al. 1981) was established based only on in situ productivity. Being motivated by this suggestion, many studies have revealed a lot of evidence that allochthonous input occurs across many habitat boundaries: between marine and terrestrial habitats (Polis \& Hurd 1996a, 1996b, Rose \& Polis 1998), between riparian forest and river (Wallace et al. 1997, Nakano et al. 1999, Nakano \& Murakami 2001, Sabo \& Power 2002), between alpine lake and alpine vegetation (Vinebrroke \& Leavitt 1998), and between rocky subtidal and intertidal habitat (Duggins et al. 1989, Duggins \& Eckman 1994, 1997, Bustamante et al. 1995, Bustamante \& Branch 1996, Hori \& Noda 2001a).

Allochthonous input has significant indirect effects on the dynamics of prey populations and communities, mediated through the consumers in the recipient habitat (Bustamante et al. 1995, Polis \& Hurd 1996b, Nakano et al. 1999, Sabo \& Power 2002). Polis \& Hurd (1996a) suggest that in a simple community with one consumer and two prey (one is allochthonous input, the other is in situ prey) that al- 
lochthonous input increases in situ consumers, and then the increased consumers decrease the in situ prey (apparent competition, Holt 1977). Previous studies have indicated that the effect of allochthonous input on the in situ prey is occasionally quite strong in many habitats (e.g. Bustamante et al. 1995, Polis \& Hurd 1996a, 1996b, Nakano et al. 1999, Jefferies 2000, Sánchez-Piñero \& Polis 2000, Nakano \& Murakami 2001, Sabo \& Power 2002, Takimoto et al. 2002).

However, allochthonous input may not always decrease in situ prey. Sabo \& Power (2002) suggest that the effects of allochthonous input on in situ prey can become positive in a short time, via implicit consumer responses. In addition, theoretical models of one predator/two prey communities suggest that the indirect effects of prey 1 on prey 2 via consumers may be either positive or negative, and the consequences of these effects depend on the predator's response (i.e. functional or numerical) to prey 1 (Holt 1977, Abrams \& Matsuda 1996, Abrams et al. 1998). These results imply that the effect of allochthonous input varies with various factors, such as the consumer response, environmental factors and time scale, suggesting that the response to allochthonous resources may be idiosyncratic. Our knowledge of allochthonous inputs is still insufficient to predict their effects on community structure and dynamics.

The rocky intertidal habitat is one that has contributed much to our understanding of community ecology (see reviews in Hairston 1996, Menge \& Branch 2001), because rocky intertidal habitat have been at the forefront of the development of ecological experimentation (Underwood 2000). Some of the acceptable theories of community ecology had been drawn up and demonstrated by manipulativeexperimental approaches in this habitat (Connell 1961a, 1961b, Paine 1966, 1969, 1992, Connell \& Slayer 1977, Paine \& Levin 1981, Underwood \& Denley 1984, Menge \& Sutherland 1987, Farrell 1991, Menge 1995). However, these traditional experiments, which have the manipulative limitation, focused on communities in small spatial scale within a patch or a habitat. The approach prevented the detection of the factors affecting community structure and dynamics on a larger scale, such as between-habitat interactions including allochthonous input.

However, it has recently become evident that rocky intertidal habitat may frequently receive allochthonous resources due to the specific physical environment with daily tidal cycle and surf. This habitat is exposed daily to both the atmospheric environment in the ebb-tide period and underwater environment in the high tide (e.g. Carefoot 1977, Raffaelli \& Hawkins 1996). This daily tidal movement brings nutrients, detritus, organic particles, and organisms from pelagic and subtidal systems to intertidal and supratidal systems (e.g. Duggins et al. 1989, Duggins \& Eckman 1994, 1997, Bustamante et al. 1995, Bustamante \& Branch 1996, Menge et al. 1997, Hori \& Noda 2001a). For example, kelp fragment and detritus (e.g. Duggins et al. 1989, Bustamante et al. 1995, Bustamante \& Branch 1996, Hori
2006), invertebrates (e.g. Hori \& Noda 2001a, Hori 2006), and fishes (e.g. Hori et al. 2002) are typical allochthonous resources from the adjacent subtidal system. Dead bodies stranded on the shore are consumed by invertebrates in both high and ebb tide period (Duggins et al. 1989, Bustamante et al. 1995, Bustamante \& Branch 1996) and by birds in the ebb-tide period (Hori \& Noda 2001a, Hori et al. 2002, Hori 2006). Bustamante et al. (1995) revealed the significant effect of drifting kelp from the subtidal habitat on herbivorous invertebrate in the intertidal habitat. The kelp subsidization increased the density of limpets 2.3-2.5 times more than the density can be retained by intertidal ephemeral algal production, although it has not been determined whether the increase of limpets affected the in situ ephemeral algal community. In order to understand the effects of allochthonous input on the rocky intertidal community, further studies examining the effects on predators that can show various feeding responses would be needed.

The ideas and problems raised by the above studies have encouraged us to demonstrate the effects of allochthonous input on the community structure and dynamics in rocky shore ecosystems. This paper reviews the effects of between-habitat interactions on the community structure and dynamics in the rocky intertidal habitat, especially focusing on my studies performed in northern Japan. First, I examine in detail the whole food web structure including the trophic links with adjacent habitats, to clarify the pathways among allochthonous input from the donor habitat, the consumers in the recipient habitat and their in situ prey. Second, I examine how the variability in allochthonous resource supply from the donor habitat affects the recipient food web structure and dynamics via consumer responses. Based on these results, I finally present a new interpretation of rocky intertidal community and discuss the importance of research on between-habitat interactions for understanding coastal ecosystems and their conservation and restoration.

\section{Food web structure of the rocky intertidal community}

Rocky intertidal habitats are characterized by a wide range of physical conditions, which are expressed mainly as horizontal gradients in wave exposure and vertical gradients in tidal excursion (Menge \& Branch 2001). Along these two dominant gradients, sessile organisms such as algae, barnacles and mussels express vertical zonation. Mobile animals including gastropods, limpets, small crustaceans and other movable invertebrates are also distributed along these gradients of physical conditions and interact with sessile organisms. In addition, larger predators with higher mobility, such as fishes, birds and mammals forage in the rocky intertidal habitat (Carefoot 1977, Menge \& Sutherland 1987). These sessile and mobile organisms are major components of the rocky intertidal food web structures although its structure varies depending on physical conditions.

The biota of rocky intertidal habitat in northern Japan 
follow the general trends mentioned above (Hori \& Noda 2001a). The dominant sessile organisms form clear intertidal zonation; the highest horizontal zone is the mixed zone of barnacle and red alga, followed by the Fucus zone, mussel zone, coralline zone, Sargassum zone, surfgrass zone, and kelp zone (see detail in Hori \& Noda 2001a). Many gastropod, limpet and small crustacean species use the sessile organisms as food resources or inhabiting substrates (Hori \& Noda 2001a, 2001b, Noda et al. 2003, Hori et al. 2006). The top predators are bird and fish species (Hori \& Noda 2001a), which have strong top-down effects on their prey species and community structure (Hori \& Noda 2001b, Hori et al. 2006). In order to construct the whole food web structure including the trophic linkages between the rocky intertidal community and allochthonous resources from adjacent systems, all trophic interactions were determined using field observation, gastrointestinal contents and fecal analyses (see details of methods in Hori \& Noda 2001a).

The food web structure was constructed by all trophic linkages including 92 taxonomical species and 6 trophospecies (drifted subtidal algae, fish egg, fishery waste, detritus, epiphytic diatoms and phytoplankton) (Fig. 1). Among them, 15 species were allochthonous resources from vari- ous adjacent systems and consumed mainly by avian species of top predators. In particular, the crow and gull species were dominant and frequently consumed allochthonous sea urchins from the subtidal habitat (Hori \& Noda 2007). The sea urchins not eaten by avian predators died because heat and drought in the intertidal habitat from spring to autumn are approximately lethal to them (Hori \& Noda 2001a, Hori 2006). The trophic interaction between the avian predators and the sea urchins was the most dominant of all trophic linkages between the intertidal species and allochthonous inputs (Hori \& Noda 2001a), suggesting that the dominant interaction between the donor habitat and the recipient habitat would be represented as the pathway from the allochthonous sea urchins to the intertidal prey species mediated by avian consumers. Therefore, I examined second the significance of the pathway.

\section{Allochthonous input affects food web structure and dy- namics mediated by consumer foraging responses}

The consequence of the effect of allochthonous input on the recipient community was different between empirical and theoretical studies. Many empirical studies suggest that allochthonous resources directly increase the consumers

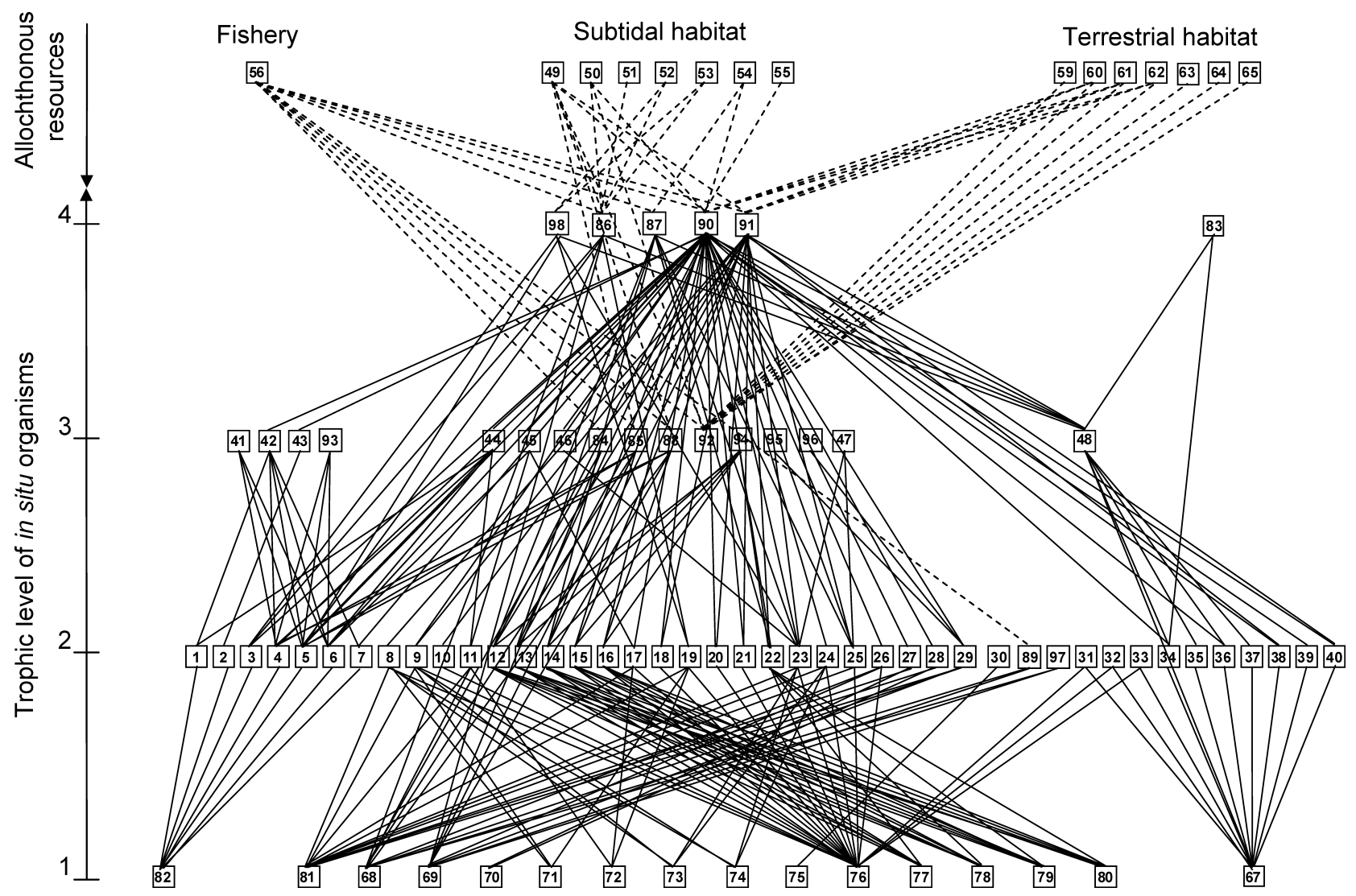

Fig. 1. Cumulative food web structure in the intertidal zone (modified from Hori \& Noda 2001a). Observed trophic interactions among organisms living on the intertidal habitat are shown by solid lines. Allochthonous resources forming fishery, terrestrial and subtidal habitats related to the intertidal food web are connected with dotted lines. Species that did not have any trophic interactions with other organisms were removed from the food web. See Appendix for code to abbreviations. 
and indirectly decrease the abundance of in situ prey species through the increased consumers (Polis \& Hurd 1996b), whereas theoretical models demonstrate that consequences of the indirect effects between allochthonous resources may be both positive and negative depending on the type of the predator's response to subsidies (Holt 1977, Abrams \& Matsuda 1996, Abrams et al. 1999). The study of the rocky intertidal community also demonstrated that the increase of limpets was caused by the increase of drift algae (Bustamante et al. 1995, Bustamante \& Branch 1996). This limpet's response on kelp subsidy may be typically numerical because many limpet individuals died when the kelp subsidy was removed. In this case, allochthonous input should indirectly decrease in situ prey via the increase of consumer density. However, the consequence of the effect of the increased limpets on in situ algae would depend on the functional response of the limpet. For example, the indirect effect of allochthonous drift algae on the in situ algae may be positive if the limpets selectively feed on only drift algae when the drift algae were abundant, whereas the indirect effect may be negative if the limpets feed on both the drift algae and the in situ algae. This idea suggests that examination of both numerical and functional response to the allochthonous input needs to be demonstrated for further understanding of the effects of allochthonous resource supply to the recipient community structure and dynamics.

In the rocky intertidal habitat of northern Japan, allochthonous sea urchins from subtidal habitat are fed by crow and gull species (Hori \& Noda 2001a, Hori \& Noda 2007). The birds can respond immediately both numerically (i.e. aggregating into the resource) and functionally (i.e. prey switching) to the change of their food availability. These birds feed on both allochthonous sea urchin and many intertidal prey species (Hori \& Noda 2001a) and their feeding effects on the intertidal prey are significant (Hori \& Noda 2001b, Hori et al. 2006). Therefore the amount of intertidal prey consumed by each avian consumer would vary with the sea urchin subsidy via the functional or numerical responses of the birds.

In order to demonstrate this hypothesis, I investigated avian feeding, the abundance of the allochthonous sea urchins, and the intertidal prey species using a series of census on birds (Hori \& Noda 2001a), allochthonous sea urchins (Hori 2006), and intertidal prey species (Hori 2003), respectively. The investigation was conducted for three years when each year has different oceanographic conditions. Based on this, I examined the interannual variation in the rocky intertidal community with the gradient in the amount of sea urchin input and discuss the effects of allochthonous input on the recipient communities associated with consumer responses.

The study site is located at a front of the Kurile current (Oyashio) from the Bering Sea meeting the branch of Japan current (Tsugaru warm current) from the Japan Sea. Their strengths vary seasonally and annually (e.g. Noda 2004). Because the area is located near the boundary where the

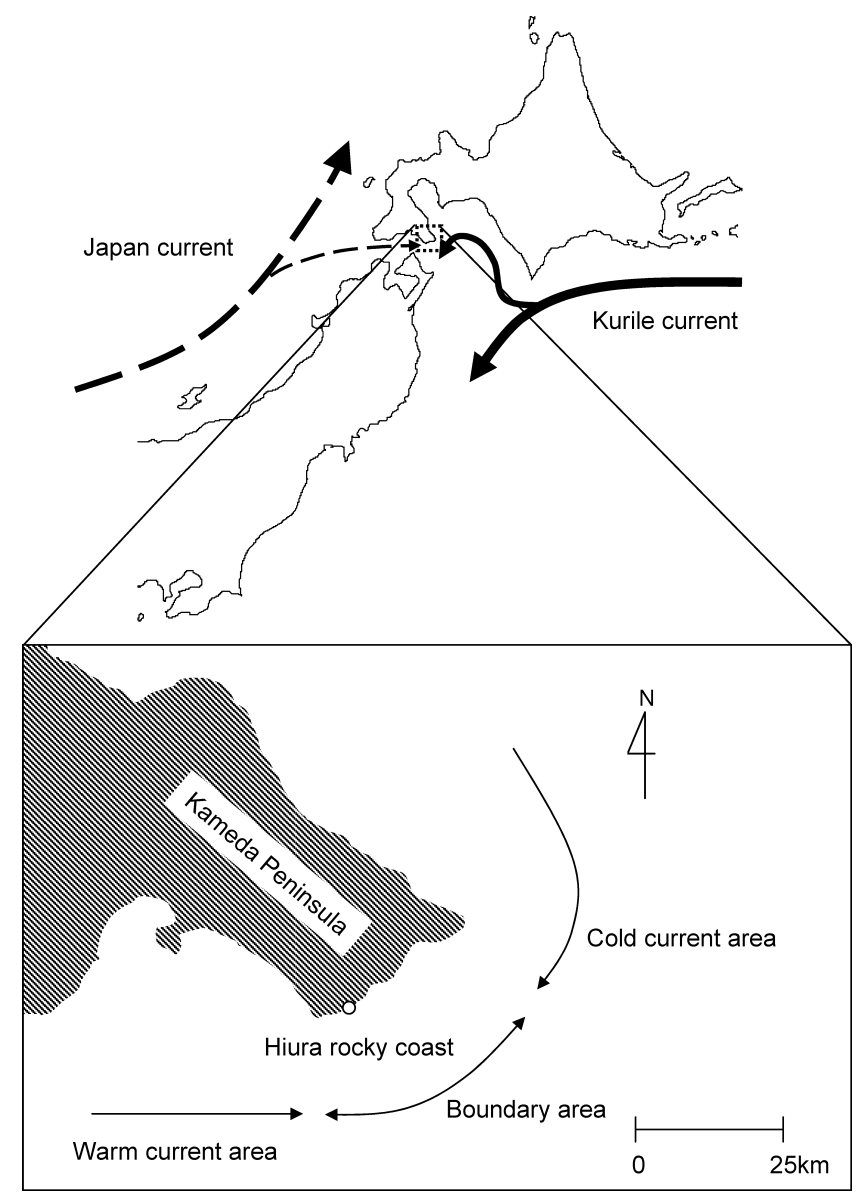

Fig. 2. Study site of Hiura rocky coast, Kameda Peninsula, Hokkaido, Japan.

two currents meet (Fig. 2), the variability in their relative strength is likely to affect local environmental conditions, especially water temperature. The study was performed for three years with different oceanographic conditions: between August 1997 and July 1998 (this period was defined as the year 1998) when the Japan current was relatively weak in summer (Hakodate Marine Observatory 1997, 1998), between August 1999 and July 2000 (defined as the year 2000) when the Japan current was relatively strong in summer (Hakodate Marine Observatory 1999), and August 2000 and July 2001 (defined as the year 2001) when the strength of the Japan current balanced with that of the Kurile current in summer (Hakodate Marine Observatory 2000, 2001).

These interannual differences in oceanographic conditions may affect the allochthonous sea urchin supply. This is because that interannual variation in sea urchin subsidy is related to population dynamics of the subtidal sea urchins, which are regulated by high water temperature in summer (Nishihama 1993, Otsuki 1994). During the study period, mass mortality of the subtidal sea urchins actually occurred in the 1999 (Sakamoto 2000).

The results of my investigation revealed that the subsidy rate of sea urchins clearly differed from year to year (Fig. 


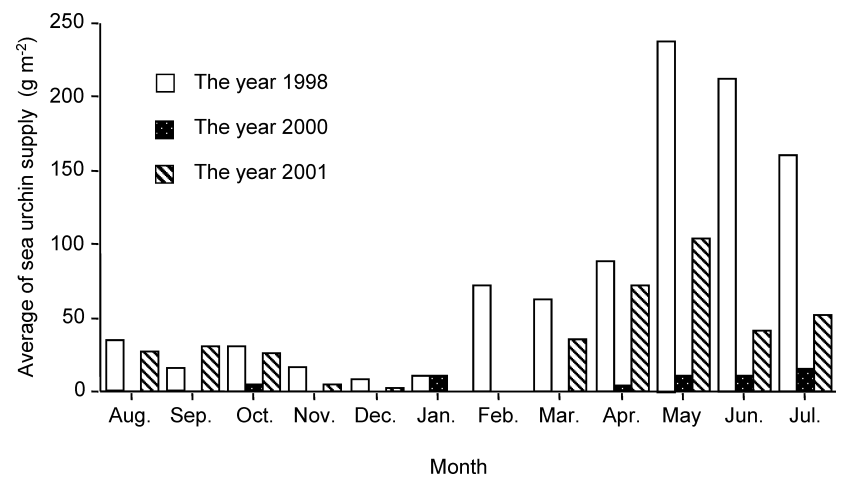

Fig. 3. Seasonal and interannual variation in the number of sea urchin (Strongylocentrotus intermedius) subsidized from subtidal to intertidal habitat.

3). One way ANOVA showed that the difference of the subsidy rate among years was significant $(F=9.683, p=0.001)$; the highest was in the year 1998, followed by the year 2001 and the year 2000 .

In response to the interannual difference in the sea urchin supply, the number of gulls foraging in the intertidal habitat showed clear difference among years (Fig. 4b, One-way ANOVA, $F=32.330, p<0.0001)$. The mean number of gulls in the year 1998 was the highest, followed by that in the year 2001, and the lowest in the year 2000. On the other hand, the number of carrion crows foraging in the intertidal habitat did not significantly change among years (Fig. 4a, One-way ANOVA, $F=2.081, p=0.1487$ ). However, the number of the fledglings varied among years: 3, 0 , and 1 in the year 1998, the year 2000, and the year 2001, respectively.

In addition, the interannual variation in prey consumption by the crow and gull species exhibited different patterns (Fig. 5a and 5b). The annual consumption of sea urchins by the crows was largest in the year 1998 followed by that in the year 2001, and least in the year 2000. In contrast, the intertidal prey was least consumed in the year 1998 and most in the year 2000. The gulls showed the largest consumption of sea urchin in the year 1998 followed by that in the year 2001 and the least in the year 2000, and showed the largest consumption of the intertidal prey in the year 1998 and the least in the year 2000 .

Following the interannual variation in the avian consumption, the biomass of dominant intertidal prey species exhibited a contrasting pattern between crows and gulls (Fig. 6). Nucella freycineti and upper Pseudopotamilla occelata showed a similar pattern to the sea urchin subsidy; the highest density of prey was in the year 1998, and the lowest density was in the year 2000. In contrast, the interannual variation in the density of lower P. occelata and Hyale grandicornis showed the opposite pattern to the interannual variation in the subsidy rate of sea urchin.

My findings have some important implications. First, both avian predators consumed the sea urchins from the subtidal habitat the most of all prey species in the intertidal (a)

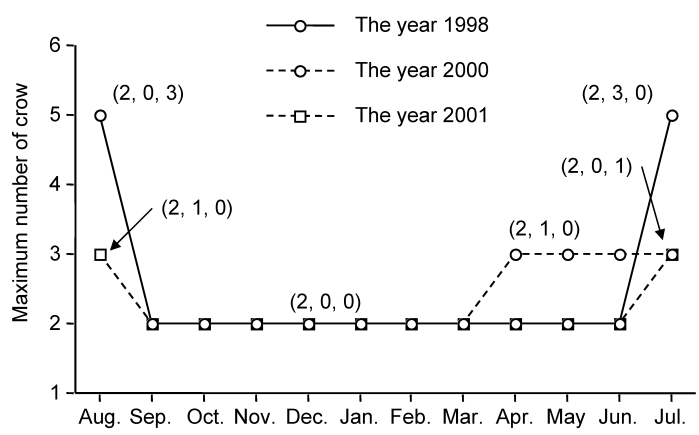

(b) Month

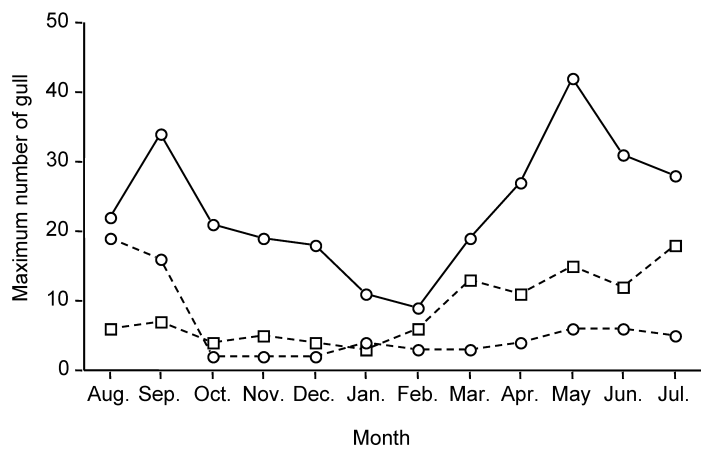

Fig. 4. Maximum number of (a) crows and (b) gulls in each month for three years. The numbers in each parentheses in (a) show the number of adult, helper and fledglings of the crow species by turns.

habitat, although the foraging behavior was clearly different between them. The gull species can be considered as recipient predators that exhibit both functional and numerical response to food availability, whereas the crow species can be considered as recipient predators that do not exhibit their numerical but only functional response to food availability. This is because a pair of the crows established a breeding territory including the whole intertidal area of the study site, excluding any other individuals of the same species (Hori \& Noda 2001a). The crows actually fed on more intertidal prey in the year when the sea urchin supply was lower (Fig. 5a), suggesting that they switched their food items from sea urchin to the intertidal prey when their favorite prey, sea urchins, were quite few. Therefore, the crow's total response to the allochthonous input can be actually explained by functional response.

On the other hand, the gulls fed on few intertidal prey in the year when sea urchin supply from the subtidal habitat was low. The gulls would change their arrival frequency at the study site depending on its suitability as a feeding site because they have a relatively broad feeding range, which includes other shores and the fishery ports around their breeding and roosting colony (Hori \& Noda 2001a). Sea urchin subsidy would increase the quality of the study area, as gull's foraging habitat. Therefore their response to the sea urchin subsidy may be rather aggregative, which makes 


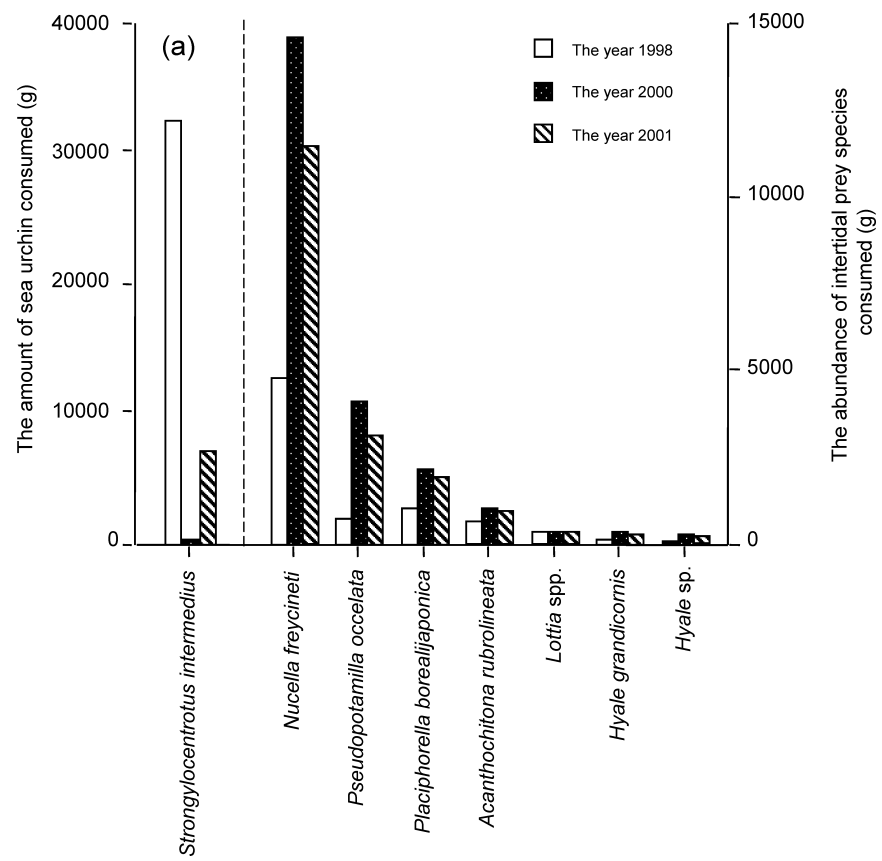

(b)

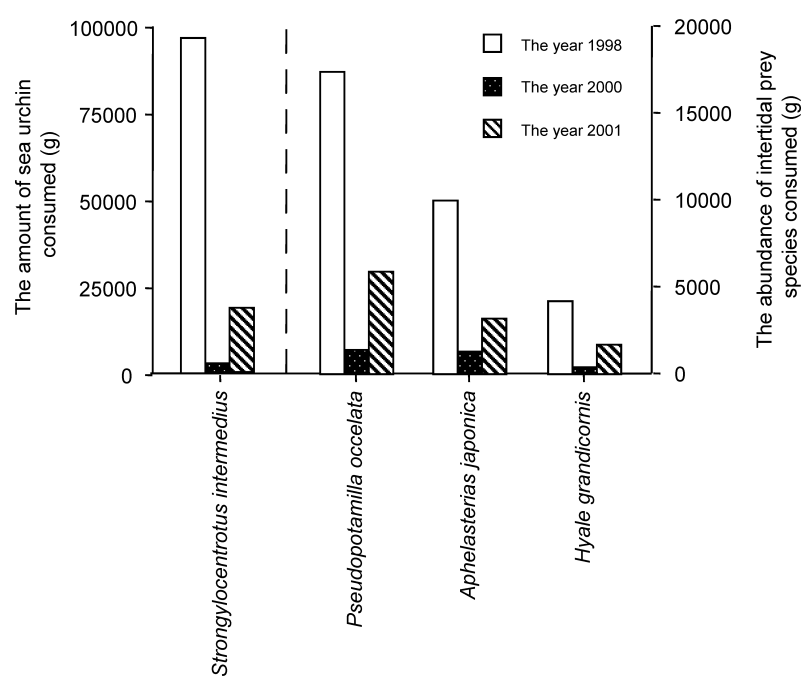

Fig. 5. The amount of sea urchin and major intertidal species consumed by (a) the crow species and (b) the gull species. Open bars show those in the year 1998, shaded bars show those in the year 2000, and oblique-line bars show those in the year 2001.

the effect of gulls on in situ prey stronger when the allochthonous input is abundant. In other word, allochthonous input usually strengthens the effect of gulls on in situ prey.

In summary, for crow species, the increase of allochthonous input let them forage toward sea urchin, and thus the effect of the crow on the in situ prey becomes weak. For gull species, in contrast, the increase of allochthonous input let them aggregate in the study site to forage sea urchin, and thus the effect of the gull on the in situ prey becomes strong. The difference between their effects on in situ preys would surely depend on their foraging behaviors and their

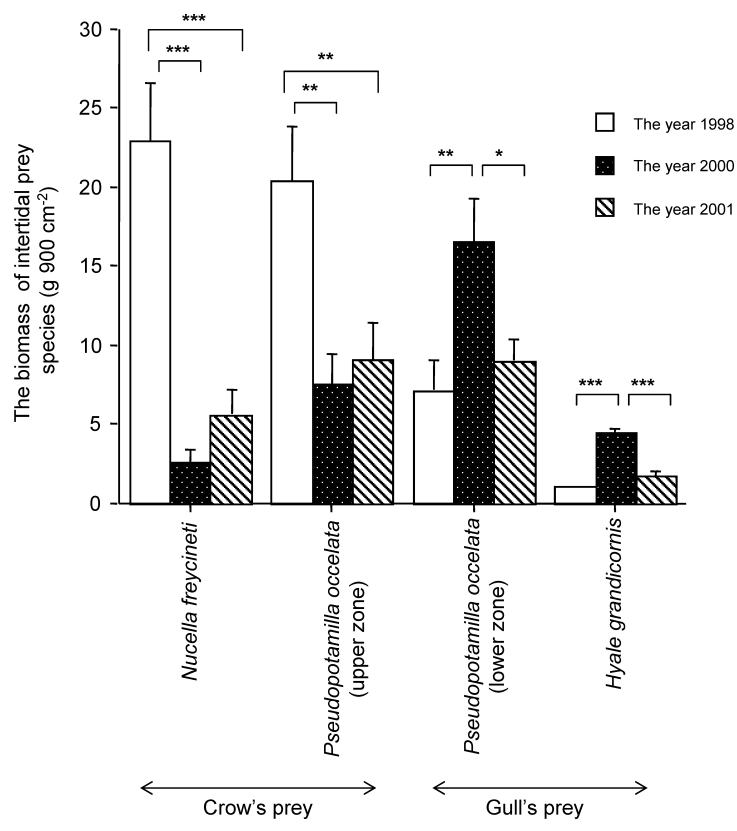

Fig. 6. Interannual variation in the biomass of major intertidal prey species. The top two highly-consumed preys of crows were Nucella freycineti followed by Pseudopotamilla occelata in upper zone and those consumed by gulls were $P$. occelata in lower zone and Hyale grandicornis. This was censused yearly in July when crows finished their breeding that need the most abundant prey in all season. Open bars show those in the year 1998, shaded bars show those in the year 2000 and oblique-line bars show those in the year 2001. Significant $p$-values are represented by asterisks: $* p<0.05$; ** $p<0.01$; *** $p<0.001$.

preference of prey.

In general, allochthonous input facilitates the increase in the recipient consumers (Polis \& Strong 1996, Polis et al. 1997b), and the consumers' top-down effect on in situ prey is often negative (Polis \& Hurd 1996a, Polis \& Strong 1996, Polis et al. 1996), and occasionally positive (Sabo \& Power 2002). The results of my investigation clearly suggested that the difference in the effect of consumer on in situ prey may depend on the consumer's traits: i.e., the foraging behavior and the social behavior regulating their number in their foraging patch. Based on my findings, the relative important consumer-response and their effects on in situ prey may be classified as three cases as follows. In case (1), the consumer density in the resource patch is certainly regulated by social interaction (i.e. territorial defense: this study). In this case, the consumer's total response may be explained by functional-response; they would selectively feed allochthonous resource and less in situ resource (weaken the effect on in situ prey) (i.e. probably, lizards: Sabo \& Power 2002, crows: this study). In case (2), the consumer density in the resource patch is regulated by resource level rather than their own density (i.e. predator density independence, Holt 1977), and moreover the consumers can use other foraging patches. In this case, the consumers can aggregate in the best profitable patch with al- 
lochthonous resource (aggregative response). Therefore they would depress in situ prey in the patch with allochthonous input (i.e. gulls in this study, coyotes: Rose \& Polis 1998). In addition to case (2), the other case where the consumers can not use other foraging patches must be considered. This is because the consumer's aggregative response does not occur but the numerical response occurs in this case, resulting in the different consequence of the consumer-prey interaction from case (2). This is the case (3), in which the consumer density in the resource patch is regulated by resource level rather than consumer density. Here, the consumers do not use other foraging patches. In this case, consumer numerical response may be relatively important rather than functional one; the consumers can increase their density more than that can be retained by in situ resource due to allochthonous resource. After then, the increased consumers would depress in situ prey when the allochthonous resource decrease (i.e. spiders: Polis \& Hurd 1996a, limpets: Bustamante et al. 1995).

\section{Future direction of research on between-habitat interac- tions in coastal ecosystems}

This series of studies demonstrated that the interaction between avian predator and allochthonous resource was an important factor regulating the food web structure and dynamics in the rocky intertidal habitat. This fact supports the recent general view that intertidal food webs are greatly subsidized by various allochthonous resources (Menge \& Branch 2001). The intertidal suspension feeders are facilitated by phytoplankton from oceanic pelagic systems (Menge et al. 1997) and detritus from subtidal systems (Duggins \& Eckman 1984, Bustamante \& Branch 1996). The intertidal grazers are subsidized by kelp fragments from subtidal system (Bustamante et al. 1995, Hori 2006). In addition, the intertidal avian predators are facilitated by subtidal invertebrates and fishes (Hori \& Noda 2001a, Hori et al. 2002, Hori 2006, Hori \& Noda 2007). Although only intertidal algae are suggested as the in situ primary producers, even they are affected by upwelling nutrients from deep sea (Menge et al. 1996, Menge et al. 1999).

These phenomena can lead to a new conception of rocky intertidal communities as shown in Fig. 7. Various new aspects examined in the present study and recent studies can be added to the classical view such as patch dynamics (Paine \& Levin 1981) with community succession (e.g., Connell \& Slayer 1977, Sousa 1985, Farrell 1991, Benedetti-Cecchi 2000) and larval recruitment (e.g., Underwood \& Delay 1984, Underwood \& Fairweather 1989) for community organization. Avian and mammal top predators with high mobility can affect all trophic levels in all patches at all succession stages, depending on their foraging behaviors. The foraging behaviors depend on the difference of resource availability between rocky intertidal and other habitats. Nutrients, detritus, phytoplanktons transported from other habitats may potentially have bottom-up effects on

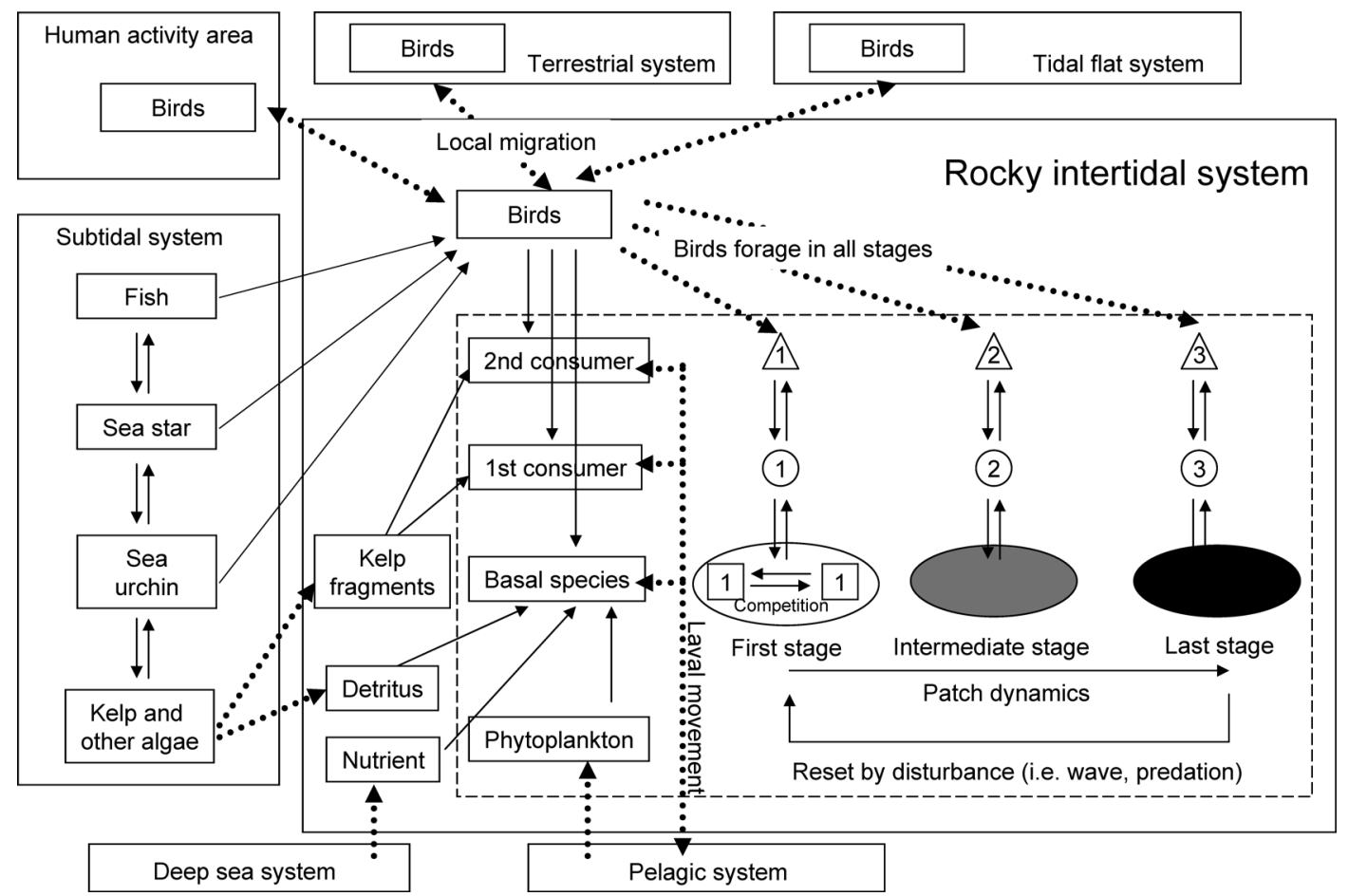

Fig. 7. A schematic interpretation of new aspects of rocky intertidal community structure. The square with broken lines shows the previous aspect of intertidal community structure. In the broken line, square, circles and triangles with each number show the sessile organisms, the first consumers and the second consumers in each stage, respectively. Solid arrows show trophic interactions and dotted arrows show the movement of nutrient, detritus, organic materials, lavae, and consumer. 
patch dynamics. Subtidal kelp fragments, marine invertebrates, and fishes subsidize the intertidal consumers including birds, and thus affect the community structure and dynamics through the consumer responses. These aspects suggest that further studies undertaken not only at a patch level but also at landscape levels (i.e., a whole coastal system) would be needed to predict the community structure and dynamics.

Lastly, the present paper emphasizes that understanding the effects and importance of between-habitat interactions on the community structure and dynamics is necessary for a better promotion of coastal conservation and restoration. The restoration and conservation project of a particular habitat may cause different consequences depending on whether the objective habitat is a recipient or donor of allochthonous resources. In the case where the objective habitat is a recipient, even a large effort to maintain or reestablish the in situ productivity and physical environments would contribute less to the conservation or restoration of the original community structure. Although the conservation of the objective habitat is often conducted by the establishment of protected areas only for the objective areas, real conservation would require the protection of the adjacent habitats that interact with the objective habitat. In addition, the restoration of the objective habitat would also need to re-establish both the in situ environments and the betweenhabitat interactions. For example, the conservation or restoration of rocky intertidal communities would need the conservation or restoration of the adjacent subtidal systems that provide many allochthonous resources (e.g., Bustamante et al. 1995, Hori 2006, this study).

In the other case, where the objective habitat is a donor, the objective habitat would be considered as a hotspot of biological production that facilitates the recipient organisms in adjacent habitats. Therefore even the establishment of protected areas only for the objective area may contribute to the conservation of the objective organisms or community structure. However, the restoration of the donor habitat may be more difficult than the restoration of the recipient habitat, because artificial manipulations in the objective habitat would also affect the adjacent habitats via allochthonous resource supply. For example, the recovery of the subtidal sea urchin population by the introduction of the artificial-cultured sea urchins affects the foraging behavior of the gull species in the intertidal habitat (Hori \& Noda 2007). This implies that the change of the gull's foraging behavior may alter the intertidal community structure. In particular, therefore, the restoration of the donor habitat should be carefully conducted with due consideration of between-habitat interactions.

In conclusion, an important aspect of the understanding of these between-habitat interactions is the clarification of the spatial extent of the community structure and dynamics at the landscape level, such as ecosystem boundary (Cousins 1996) and consumer resource shed (Power \& Rainey 2000). This is a similar idea to the metapopulation or metacommunity concept (e.g. Hanski \& Gaggiotti 2004, Holyoak et al. 2005), with respect to the demonstration of the spatial extent, influx of biological energy, linkages of community structure and dynamics, and habitat connectivity among local habitats. Further studies clarifying the consequences of between-habitat interactions would be needed to understand and predict the community structure and dynamics, which is necessary for better use and conservation of coastal ecosystems.

\section{Acknowledgements}

I would like to express my gratitude to Takashi Noda for many discussions and for his invitation to community ecology. I am grateful to S. Nakao, S. Goshima and other member of Benthos Laboratory, Hokkaido University, for their valuable comments and help in this study. I would like to thank B. Menge, T. Wootton, H. Mukai, M. Nakaoka, S. Nakano, T. Miyashita, and M. Power for their critical comments and helpful suggestions to my study. I am grateful to M. Hamaguchi, who provided me with the opportunity to present this paper in this journal. This study was partially supported by a JSPS Research Fellowship for Young Scientists.

\section{References}

Abrams PA, Matsuda H (1996) Positive indirect effects between prey species that share predators. Ecology 77: 610-616.

Abrams PA, Holt RD, Roth JD (1998) Apparent competition or apparent mutualism? Shared predation when populations cycle. Ecology 79: 201-212.

Anderson W, Polis GA (1998) Marine subsidies of island communities in the Gulf of California: evidence from stable carbon and nitrogen isotopes. Oikos 81: 75-80.

Benedetti-Cecchi L (2000) Predicting direct and indirect interactions during succession in a mid-littoral rocky shore assemblage. Ecol Monogr 70: 45-72.

Bustamante RH, Branch GM (1996) The dependence of intertidal consumers on kelp-derived organic matter on the west coast of South Africa. J Exp Mar Biol Ecol 196: 1-28.

Bustamante RH, Branch GM, Eekhout S (1995) Maintenance of an exceptional intertidal grazer biomass in South Africa: subsidy by subtidal kelp. Ecology 76: 2314-2329.

Carefoot T (1977) Pacific Seashores. University of Washington Press, Seattle, Washington, $208 \mathrm{pp}$.

Connell JH (1961a) Effect of competition, predation by Thais lapillus, and other factors on natural populations of the barnacle Balanus balanoides. Ecol Monogr 31: 61-104.

Connell JH (1961b) The influence of interspecific competition and othe factors on the distribution of the barnacle Chthamalus stellatus. Ecology 42: 710-723.

Connell JH, Slayer RO (1977) Mechanisms of succession in natural communities and their role in community stability and organization. Am Nat 111: 1119-1144.

Cousins SH (1996) Food webs: From the Lindeman paradigm to a taxonomic general theory of ecology. In: Food Webs: Integra- 
tion of patterns and dynamics (eds Polis GA, Winemiller K), Chapman \& Hall, New York, New York, pp. 243-251.

Duggins DO, Eckman JE (1994) The role of kelp detritus in the growth of benthic suspension feeders in an understory kelp forest. J Exp Mar Biol Ecol 176: 53-68.

Duggins DO, Eckman JE (1997) Is kelp detritus a good food for suspension feeders? Effects of kelp species, age and secondary metabolite. Mar Biol 128: 489-495.

Duggins DO, Simenstadand CA, Estes JA (1989) Magnification of secondary production by kelp detritus in coastal marine ecosytems. Science 245: 170-173.

Farrell TM (1991) Models and mechanisms of succession: an example from a rocky intertidal community. Ecol Monogr 61: 95-113.

Hairston NG. SR (1996) Ecological Experiments: Purpose, design, and execution. Cambridge University Press, New York, New York, 420 pp.

Hakodate Marine Observatory (1997) Oceanographic observation report of the Hakodate Marine Observatory Vol. 35. The Hakodate Marine Observatory, Hakodate, Hokkaido, 173 pp. (in Japanese)

Hakodate Marine Observatory (1998) Oceanographic observation report of the Hakodate Marine Observatory Vol. 36. The Hakodate Marine Observatory, Hakodate, Hokkaido, 133 pp. (in Japanese)

Hakodate Marine Observatory (1999) Oceanographic observation report of the Hakodate Marine Observatory Vol. 37. The Hakodate Marine Observatory, Hakodate, Hokkaido, 122 pp. (in Japanese)

Hakodate Marine Observatory (2000) Oceanographic observation report of the Hakodate Marine Observatory Vol. 38. The Hakodate Marine Observatory, Hakodate, Hokkaido, 170 pp. (in Japanese)

Hakodate Marine Observatory (2001) Oceanographic observation report of the Hakodate Marine Observatory Vol. 39. The Hakodate Marine Observatory, Hakodate, Hokkaido, 191 pp. (in Japanese)

Hanski I, Gaggiotti OE (2004) Ecology, Genetics, and Evolution of Metapopulations. Elsevier Academic Press, San Diego, California, $696 \mathrm{pp}$.

Hilderbrand GV, Hanley TA, Robbins CT, Schwartz CC (1999) Role of brown bears (Ursus arctos) in the flow of marine nitrogen into a terrestrial ecosystem. Oecologia 121: 546-552.

Holyoak M, Leibold MA, Holt RD (2005) Metacommunities: Spatial dynamics and ecological communities. The University of Chicago Press, Chicago, Illinois, 513 pp.

Holt RD (1977) Predation, apparent competition, and the structure of prey communities. Theor Popul Biol 12: 197-229.

Hori M (2003) Food web structure and dynamics attributed to avian foraging and allochthonous input in the rocky intertidal habitat. Doctoral dissertation, Hokkaido University, Hokkaido, $201 \mathrm{pp}$.

Hori M (2006) Intertidal surfgrass as an allochthonous resource trap from the subtidal habitat. Mar Ecol Prog Ser 314: 89-96.

Hori M, Noda, T (2001a) Spatio-temporal variation of avian foraging in the rocky intertidal food web. $\mathrm{J}$ Anim Ecol 70: 122-137.

Hori M, Noda T (2001b) An unpredictable indirect effect of algal consumption by gulls on crows. Ecology 82: 3251-3256.
Hori M, Noda T (2007) Avian predation on wild and cultured sea urchin Strongylocentrotus intermedius in a rocky shore habitat. Fish Sci 73: 303-313.

Hori M, Noda T, Nakao S (2006) Effects of avian grazing on the algal community and small invertebrates in the rocky intertidal zone. Ecol Res 21: 768-775.

Hori M., Noda T, Ueno Y (2002) Mechanisms of the allochthonous resource subsidies from marine to terrestrial systems via avian predator. Gekkan Kaiyou 34: 429-435. (in Japanese)

Jefferies RL (2000) Allochthonous inputs: integrating population changes and food-web dynamics. Trends Ecol Evol 15: 19-21.

Menge BA (1995) Indirect effects in marine rocky intertidal interaction webs: patterns and importance. Ecol Monogr 65: 21-74.

Menge BA, Branch GM (2001) Rocky intertidal communities. In: Marine Community Ecology (eds Bertness MD, Gaines SD, Hay ME). Sinauer Associates, Sunderland, Massachusetts, pp. 221-251.

Menge BA, Sutherland JP (1987) Community regulation: variation in disturbance, competition, and predation in relation to environmental stress and recruitment. Am Nat 130: 730-757.

Menge BA, Daley BA, Lubchenco J, Sanford E, Dahlhoff E, Halpin PM, Hudson G, Burnaford JL (1999) Top-down and bottom-up regulation of New Zealand rocky intertidal communities. Ecol Monogr 69: 297-330.

Menge BA, Daley BA, Wheeler PA (1996) Control of interaction strength in marine benthic communities. In: Food Webs: Integration of patterns and dynamics (eds Polis GA, Winemiller K), Chapman \& Hall, New York, New York, pp. 258-274.

Menge BA, Daley BA, Wheeler PA, Dahlhoff E, Sanford E, Strub PT (1997) Benthic-pelagic links and rocky intertidal communities: bottom-up effects on top-down control? PNAS 94: 14530-14535.

Nakano S, Miyasaka H, Kuhara N (1999) Terrestrial-aquatic linkages: riparian arthropod inputs alter trophic cascades in a stream food web. Ecology 80: 2435-2441.

Nakano S, Murakami M (2001) Reciprocal subsidies: dynamic interdependence between terrestrial and aquatic food webs. PNAS 98: 166-170.

Nishihama Y (1993) Between-year variation of the water temperature in the warm current area. Hokusuishidayori 21: 19-21 (in Japanese).

Noda T (2004) Large-scale variability in recruitment of the barnacle Smibalanus cariosus: its cause and effects on the population density and predator. Mar Ecol Prog Ser 278: 241-252.

Oksanen L, Fretwell SD, Arruda J, Niemela P (1981) Exploitation ecosystems in gradients of primary productivity. Am Nat 118: 240-261.

Otsuki T (1994) What happened to water temperature in the summer 1994? Shikenkenkyuuhaima 202. Department of fisheries and Forestry, Hokkaido Government, Japan. (in Japanese)

Paine RT (1966) Food web complexity and species diversity. Am Nat 100: 65-75.

Paine RT (1969) A note on trophic complexity and community stability. Am Nat 103: 91-93.

Paine RT (1992) Food-web analysis through field measurement of per capita interaction strength. Nature 355: 73-75.

Paine RT, Levin SA (1981) Intertidal landscapes: disturbance and the dynamics of pattern Ecol Monogr 51: 145-178.

Polis GA, Hurd SD (1995) Extraordinarily high spider densities 
on islands: flow of energy from the marine to terrestrial food webs and the absence of predation. PNAS 92: 4382-4386.

Polis GA, Hurd SD (1996a) Allochthonous inputs across habitats, subsidized consumers and apparent trophic cascades: examples from the ocean-land interface. In: Food Webs: Integration of patterns and dynamics (eds Polis GA, Winemiller K), Chapman \& Hall, New York, New York, pp. 275-285.

Polis GA, Hurd SD (1996b) Linking marine and terrestrial food webs: allochthonous input from the ocean supports high secondary productivity on small islands and coastal land communities. Am Nat 147: 396-423.

Polis GA, Strong DR (1996) Food web complexity and community dynamics. Am Nat 147: 813-846.

Polis GA, Holt RD, Menge BA, Winemiller KO (1996) Time, Space, and Life history: influence on Food webs. In: Food Webs: Integration of patterns and dynamics (eds Polis GA, Winemiller K), Chapman \& Hall, New York, New York, pp. 435-460.

Polis GA, Anderson WB, Holt RD (1997a) Toward an integration of landscape and food web ecology: the dynamics of spatially subsidized food webs. Ann Rev Ecol Syst 28: 289-316.

Polis GA, Hurd SD, Jackson CT, Sanchez-Pinero F (1997b) El Nino effects on the dynamics and control of an island ecosystem in the gulf of California. Ecology 78: 1884-1897.

Power ME, Rainey WE (2000) Food webs and resource sheds: Towards spatially delimiting trophic interactions. In: Ecological consequences of habitat heterogeneity (eds Huchings MJ, John EA), Blackwell Scientific, London, pp. 291-314.

Raffaelli D, Hawkins S (1996) Intertidal Ecology. Chapman \& Hall, London, $356 \mathrm{pp}$.

Rose MD, Polis GA (1998) The distribution and abundance of coyotes: the effects of allochthonous food subsidies from the sea. Ecology 79: 998-1007.

Sabo JL, Power ME (2002) River-watershed exchange: effect of riverine subsidies on riparian lizards and their terrestrial prey. Ecology 83: 1860-1869.

Sakamoto M (2000) Oceanographic condition and fisheries in the area of sea around Hokkaido. Shikenkenkyuuhaima 413. Department of fisheries and Forestry, Hokkaido Government, Japan. (in Japanese)

Sanchez-Pinero F, Polis GA (2000) Bottom-up dynamics of allochthonous input: direct and indirect effects of seabirds on islands. Ecology 81: 3117-3132.

Sousa WP (1985) Disturbance and patch dynamics on rocky intertidal shores. In: The ecology of natural disturbance and patch dynamics (eds Pickett STA, White PS), Academic Press, Orlando, Florida, pp. 101-124.

Takimoto G, Iwata T, Murakami M (2002) Seasonal subsidy stabilize food web dynamics: Balance in a heterogeneous landscape. Ecol Res 17: 433-439.

Underwood AJ (2000) Experimental ecology of rocky intertidal habitats: what are we learning? J Exp Mar Biol Ecol 250: 51-76.

Underwood AJ, Denley EJ (1984) Paradigms, explanations and generalizations in models for the structure of intertidal communities on rocky shore. In: Ecological communities (eds Strong DR, Simberloff D, Abele LG, Thistle A), Princeton University Press, Princeton, New Jersey, pp. 151-180.

Underwood AJ, Fairweather PG (1989) Supply-side ecology and benthic marine assemblages. Trends Ecol Evol 4: 16-20.

Vinebrroke RD, Leavitt PR (1998) Direct and interactive effects of allochthonous dissolved organic matter, inorganic nutrients, and ultraviolet radiation on an alpine littoral food web. Limnol Oceanogr 43: 1065-1081.

Wallace JB, Eggert SL, Meyer JL, Webster JR (1997) Multiple trophic levels of a forest stream linked to terrestrial litter inputs. Science 277: 102-104. 
Appendix. Species identification of nodes in Fig. 1 showing the rocky intertidal food web.

\begin{tabular}{|c|c|c|c|}
\hline Node no. & Species & Node no. & Species \\
\hline 1. & Chthamalus challengeri & 50. & Strongylocentrotus nudus \\
\hline 2. & Halichondria panicea & 51. & Stichopus japonicus \\
\hline 3. & Pseudopotamilla occelata & 52. & Lysastrosoma anthostictha \\
\hline 4. & Septifer virgatus & 53. & Aphelasterias japonica \\
\hline 5. & Mytilus galloprovincialis & 54. & Fish fry \\
\hline 6. & Mytilus coruscus & 55. & Fish eggs \\
\hline 7. & Balanus cariosus & 56. & Fishery waste \\
\hline 8. & Littorina brevicula & 57. & Terpnosia nigricosta \\
\hline 9. & Neritrema sitkana & 58. & Tibicen japonicus \\
\hline 10. & Granulilittorina exigua & 59. & Taxus sp. \\
\hline 11. & Chlorostoma argyrostoma & 60. & Vitaceae sp. \\
\hline 12. & Lottia cassis & 61. & Gramineae sp. \\
\hline 13. & Nipponoacmea schrenckii & 62. & Polyphaga sp.1 \\
\hline 14. & Lottia kogamogai & 63. & Polyphaga sp.2 \\
\hline 15. & Lottia lindbergi & 64. & Adephaga sp.1 \\
\hline 16. & Lottia tenuisculpta & 65. & Adephaga sp.2 \\
\hline 17. & Acmaea pallida & 66. & Clistogastra sp. \\
\hline 18. & Leptochiton assimilis & 67. & Detritus \\
\hline 19. & Cryptochiton stelleri & 68. & Monostroma angicava \\
\hline 20. & Acanthochitona rubrolineata & 69. & Kornmannia zostericola \\
\hline 21. & Ischnochiton hakodadensis & 70. & Phyllospadix iwatensis \\
\hline 22. & Lottia $\mathrm{sp}$ & 71. & Ulva pertusa \\
\hline 23. & Hyale grandicornis & 72. & Alaria crassifolia \\
\hline 24. & Hyale spp. & 73. & Pelvetia wrightii \\
\hline 25. & Parallorchestes ochotensis & 74. & Fucus distichus \\
\hline 26. & Hyale barbicornis & 75. & Gloiopeltis furcata \\
\hline 27. & Idotea ochotensis & 76. & Epiphytic diatom \\
\hline 28. & Cleantiella isopus & 77. & Porphyra yezoensis \\
\hline 29. & Pugettia quadridens & 78. & Bangia atropurpurea \\
\hline 30. & Dicranomyia monostromia & 79. & Urospora pencilliformis \\
\hline 31. & Dynoides dentisinus & 80. & Porphyra pseudolinearis \\
\hline 32. & Gnorimosphaeroma rayi & 81. & Sargassum thunbergii \\
\hline 33. & Cymodoce japonica & 82. & Phytoplankton \\
\hline 34. & Pagurus middendorffii & 83. & Myoxocephalus stelleri \\
\hline 35. & Pagurus lanuginosus & 84. & Larus canus \\
\hline 36. & Paguristes ortmanni & 85. & Larus argentatus \\
\hline 37. & Pagurus filholi & 86. & Larus schistisagus-adult \\
\hline 38. & Phascolosoma scolops & 87. & Larus crassirostris \\
\hline 39. & Marphysa sanguinea & 88. & Larus glaucescens \\
\hline 40. & Terebellida $\mathrm{sp}$. & 89. & Larus hyperboreus \\
\hline 41. & Ocenebra endermonis & 90. & Corvus corone-adult \\
\hline 42. & Nucella freycineti & 91. & Corvus corone-juvenile \\
\hline 43. & Velutina pusio & 92. & Corvus macrorhynchos \\
\hline 44. & Thais clavigera & 93. & Histrionicus histrionicus \\
\hline 45. & Neptunea soluta & 94. & Haematopus ostralegus osculans \\
\hline 46. & Anthopleura kurogane & 95. & Motacilla alba \\
\hline 47. & Hemigrapsus sanguineus & 96. & Monticola solitarius \\
\hline 48. & Placiphorella borealijaponica & 97. & Branta bernicla \\
\hline 49. & Strongylocentrotus intermedius & 98. & Larus schistisagus-juvenile \\
\hline
\end{tabular}

